\title{
Розанна Бенаккьо
}

Университет в Падуе

rosanna.benacchio@unipd.it

\section{Rosanna Benacchio}

University of Padua

rosanna.benacchio@unipd.it

\section{СУФФИКС -INАT В РЕЗЬЯНСКОМ ДИАЛЕКТЕ И ЕГО ПАРАЛЛЕЛИ В СЕРБСКОМ И ХОРВАТСКОМ ЯЗЫКАХ ${ }^{1}$}

\author{
THE SUFFIX -INAT IN THE RESIAN DIALECT \\ AND ITS SERBIAN AND CROATIAN PARALLELS
}

В статье рассматривается суффикс -inat, употребляемый в резьянском диалекте (в восточной части Фриули, на границе Италии со Словенией) для маркирования заимствованных глаголов романского (в основном фриульского) происхождения. Это биаспективные глаголы, чаще всего принадлежащие к международной книжной лексике. Выдвигается гипотеза о том, что суффикс появился под влиянием немецкого языка (точнее, окончания -еп инфинитива), сыгравшего немаловажную роль в развитии резьянского диалекта по крайней мере до XV века, т. е. до падения Аквилейского патриархата и вхождения Фриули в Венецианскую Республику. Аналогичный процесс наблюдается в сербском и, хотя в меньшей мере, хорватском языках в отношении суффикса -isati, также маркирующего биаспективные заимствованные глаголы, принадлежащие к международной лексике, и считающегося результатом интеграции суффикса -s- греческого аориста.

Ключевые слова: глагольные заимствования, резьянский диалект, суффикс -inat, сербский и хорватский языки, суффикс-isati.

The article deals with the suffix -inat, found in the Resian dialect (spoken in the eastern part of Friuli, on the border of Italy and Slovenia) and marking verbs borrowed from Romance (mainly Friulian). These are biaspectual verbs, mostly part of the international lexicon of Latin origin. The assumption is that the suffix arose under German influence (more precisely moulded on the infinitive ending -en), as the German language played an

1 Первая неопубликованная версия данной работы была представлена на Международном конгрессе славистов, состоявшемся в Белграде (20-27.VII.2018).

Выражается благодарность информантам и вообще тем, кто помог мне своими советами и опытом. Это Никола Ди Ленардо (Nicola Di Lenardo), Сандро Куалья (Sandro Quaglia), Луиджа Негро (Luigia Negro), Сильвана Палетти (Silvana Paletti), и, не в последнюю очередь, Хан Стэнвейк (Han Steenwijk). 
important role in the development of the Resian dialect at least until the 15th century, i.e. before the fall of the Patriarchate of Aquileia and the annexation of Friuli by the Venetian Republic. A similar process is observed in Serbian and albeit to a lesser extent in Croatian with the -isati suffix, which also marks biaspectual borrowed verbs from the international lexicon and is considered the result of the integration of the -s suffix originally forming the Greek aorist.

Keywords: verbal loanwords, Resian dialect, suffix -inat, Serbian language, Croatian language, suffix -isati.

\section{Введение}

В предыдущих работах, посвященных анализу морфологических средств грамматикализации глагольного вида и, в частности, проблеме интеграции заимствованной глагольной лексики в резьянском диалекте, обращалось внимание на существование определенного морфологического класса глаголов, характеризующегося особым, загадочным окончанием -inat, не встречающимся в соседних словенских диалектах Фриули (т. е. в терском и надижском $)^{2}$ и вообее не засвидетельствованным в славянском языковом ареале (Бенаккьо 2017). Речь идет об открытом, весьма продуктивном классе глаголов, принадлежащих преимущественно к книжной сфере, которые восходят к международной лексике романского (точнее, латинского) происхождения.

Эти глаголы выделяются в резьянской глагольной системе и по другой причине: в отличие от большинства глаголов иностранного происхождения, которые с большой регулярностью создают видовой коррелят, тем самым образуя видовую пару르, глаголы на -inat ведут себя как биаспективы: они являются аспектуально нейтральными и употребляются в функции как СВ, так и НСВ. Иными словами, они, за редкими исключениями ${ }^{4}$, не интегрируются в видовую систему славянского (в данном случае словенского) языка-реципиента. См., например, следующие случаи употребления того же самого глагола в прошедшем времени в функции как CB, так и HCB: «Wčera an mi proponinalbi-pf nö dëlö» ‘Вчера он предложил мне дело’ и «Won an mi rüdi proponinalbi-ipf za forinat» 'Он всегда предлагал мне попутеше-

2 Напомним, что резьянский диалект вместе с терским и надижским принадлежит к группе сохранившихся словенских лингвистических островов, бытующих в северо-восточной Италии, в области Фриули, на границе со Словенией. Все эти диалекты жили веками в контакте с романским языковым ареалом, поддаваясь влиянию прежде всего фриульского, затем также венецианского и, наконец, итальянского. Однако, как известно, в более древнее время, перед тем как область отошла к Венецианской Республике, во время владения Аквилейского патриархата (и раньше, до этого, с момента создания Фриульской марки Карлом Великим), эти диалекты были подвержены влиянию и немецкого языка, особенно на лексическом уровне. Об историко-географической картине т. н. «словенских диалектов Фриули», см. Бенаккьо 2002: 263-270 и Benacchio 2002: 63-70.

3 Чаще всего это осуществляется посредством первичной суффиксации. О способах образования видовых пар при заимствовании глаголов в резьянском диалекте, см. подробно Бенаккьо, Стэнвейк 2017: 32-35 и Бенаккьо 2018: 12-17.

4 См., напр., глагол sucëdinat (se) 'происходить/произойти', имеющий в качестве коррелята НСВ (правда, только с итеративным значением) sucedinüwat (se). 
ствовать'. См. также: «Wčera an jë vïnčinalbi-pf won, nys si vïnčinala bi-pf jä» 'Вчера выиграл он, сегодня выиграла я' и «An jë rüdi vïnčinalbi-ipf » 'Он всегда выигрывал' и т. п.

Кроме того, эти глаголы выделяются и другой особенностью, просодического типа: их ударение всегда падает на основу, точно так же, как и в исконных романских глагольных формах. В самом деле, все современные резьянские глаголы на -inat восходят к III романскому классу спряжения, т. е. к латинскому классу глаголов на -е̌re, охарактеризованных именно ударением на основе (Бенаккьо, Стэнвейк 2018: 34, сн. 15). Интересно, что таким образом ударение глагола в конечном счете падает на третий слог от конца, что вообще не типично для резьянской глагольной акцентной системы.

В другой работе (Benacchio, в печати) мы вернулись к теме и предположили, что происхождение этого суффикса, возможно, объясняется теми же механизмами, которые повлияли на возникновение суффиксов -isati и -irati в сербском и хорватском языках.

В настоящей работе мы возвращаемся к этой гипотезе, углубляя наш анализ. В первом параграфе (§ 1) мы будем анализировать резьянские глаголы на -inat, начиная с многочисленных глаголов романского происхождения (§ 1.1), переходя потом к более редким глаголам германского происхождения (§ 1.2). Затем мы будем анализировать глаголы на -isati (§ 2) и на -irati (§3) в сербском и хорватском языках.

\section{1. Глаголы на -inat в резьянском диалекте}

\section{1. Глаголы романского происхождения}

Начнем с резьянских глаголов на -inat романского происхождения, приведя список некоторых из наиболее употребительных, взятых из Steenwijk 1992: 237-338 и Steenwijk 2005.

Глаголы приводятся вместе с итальянской инфинитивной формой, хотя в некоторых случаях вполне возможно, что языком-донором или по крайней мере языком-посредником оказался скорее фриульский, сильно повлиявший на резьянский диалект как на уровне лексики, так и на других языковых уровнях. Кроме того, среди возможных романских источников, которые могли играть эту роль, нельзя исключить и венецианский язык. Как отмечает Х. Стэнвейк, в большинстве случаев между глагольными формами из этих трех идиомов (повторим, итальянский, фриульский и венецианский) отсутствуют яркие фонологические и семантические различия, которые дали бы нам возможность точно определить источник (Бенаккьо, Стэнвейк 2018: 32-33). В приведенных ниже глаголах, например, различия в формах инфинитива совсем малы и касаются в основном окончания инфинитива: окончанию -еre итальянских глаголов соответствуют -er в венецианских глаголах и -і в фриульских (см. ит. assistere, dipendere, dividere и т. д., вен. assister, dipender, divider, фр. assisti, dipendi, dividi). 
Однако, на наш взгляд, решение проблемы установления точного происхождения заимствованного глагола не является столь важным, тем более что, как уже было сказано, интересующие нас глаголы принадлежат в основном к международной, «книжной» лексике, и в любом случае фриульский язык смог бы, несомненно, играть по крайней мере роль посредника. Приведем в пример некоторые глаголы на -inat:

\begin{tabular}{|c|c|c|}
\hline ašištinat & (ср. ит. assistere) & 'ухаживать' \\
\hline dipendinat & (ср. ит. dipendere) & 'зависеть' \\
\hline dišperdinat & (cp. ит. disperdere) & 'растрачивать/растратить' \\
\hline dištïngvinat & (ср. ит. distinguere) & 'отличать/ отличить' \\
\hline divïdinat & (ср. ит. dividere) & ‘делить / разделить’ \\
\hline fïnğinat & (ср. ит. fingere) & ‘делать/сделать вид’ \\
\hline fondinat & (ср. ит. fondere) & 'растворяться/раствориться' \\
\hline inklüdinat & (cp. ит. includere) & ‘включать / включить’ \\
\hline konfondinat & (ср. ит. confondere) & 'мутить' \\
\hline (se) našinat & (ср. ит. nascere) & ‘рождаться / родиться’ \\
\hline proponinat & (cр. ит. proporre (< proponěre) & 'предлагать / предложить’ \\
\hline rakoljinat & (cp. ит. raccogliere) & ‘собирать/собрать’ \\
\hline sucëdinat & (ср. ит. succedere) & ‘происходить/произойти’ \\
\hline vïnčinat & (ср. ит. vincere) & ‘побеждать /победить’ \\
\hline
\end{tabular}

Таких глаголов можно было бы привести много. Они составляют открытый класс, отличительными чертами которого являются, повторим, регулярное ударение на основе (на третьем слоге от конца), биаспективность и принадлежность к книжной международной лексике латинского происхождения.

\section{2. Глаголы германского происхождения}

В резьянском диалекте то же самое окончание -inat встречается также, хотя и в несравнимо меньшей мере, в некоторых глаголах германского происхождения. Ниже мы перечислим глаголы, зарегистрированные Стенвэйком при опросе информантов в современном резьянском диалекте (Steenwijk 1992 и 2005). Список будет дополняться глаголами, приведенными М. Матичетовым в его работе о немецких заимствованиях в резьянском диалекте, опубликованной в 1975 г. (Matičetov 1975). Для всех глаголов мы постараемся восстановить период их возможного заимствования, основываясь на результатах этимологических исследований Striedter-Temps 1963, Bezlaj 1976-2007 и Snoj 2003.

Стэнвейк приводит следующие глаголы на -inat, имеющие германское происхождение:

$\begin{array}{ll}\text { namulinat } & \text { 'украшать/украсить' } \\ \text { pücinat } & \text { 'убирать/убрать' } \\ \text { šeginat se } & \text { 'происходить/произойти' } \\ \text { trücinat } & \text { 'настаивать/настоять' } \\ \text { žlajfinat } & \text { 'точить/наточить (ножи)' }\end{array}$


Глагол namulinat приводится Стридтер-Темпс в бесприставочной форме mâlati ${ }^{5}$, восходящей, по ее мнению, либо к двн. mâlôn, либо к нвн. mâlen (см. нем. malen) (Striedter-Temps 1963: 175). Bezlaj (1976-2007: 163) также приводит форму mâlati, с той же периодизацией. Этот глагол, который, видимо, появлялся чаще всего в форме $\mathrm{CB}$ с приставкой па-, что и привело к полной ее универбации, все еще используется в резьянском диалекте.

Глагол pücinat, точнее, pucat, засвидетельствован в работе StriedterTemps (1963: 202). По мнению автора, глагол восходит к нвн. putzen (см. омонимичный современный немецкий глагол рutzen 'натирать/натереть').

Что касается глагола žlajfinat, Striedter-Temps (1963: 252) связывает его (точнее, žlajfat) с свн. формами sleifen/sleipfen (см. нвн. schleifen/schleppen 'точить ножи', 'тянуть'.

Труднее установить эпоху заимствования глаголов šeginat se (см. нем. geschehen) и trücinat (см. нем trotzen), не появляющихся в используемых нами здесь этимологических словарях. Однако, что касается первого глагола, Стэнвейк связывает его с свн. geschëhen, точнее, с его вариантом, типичным для т. н. «городского каринтийского» идиома, для которого характерно употребление взрывного заднеязычного звонкого согласного вместо исконного фрикативного (Steenwijk, in c. di st.).

В процитированной выше статье Matičetov 1975 засвидетельствованы и другие глаголы германского происхождения. Они приводятся ниже с указанием вида, лексического значения и немецкой исконной глагольной формы - так, как это было предложено автором статьи:

bondrinat impf. (ср. нем. wandern)

(sa) kertinat impf. (ср. нем. sich gehören)

meltinat impf. (ср. нем. melden)

[pahtinat] impf. (cр. нем. beachten)

peglinat impf. (ср. нем. bügeln)

ragirinat impf. (ср. нем. regieren)

[rajtinat] impf. (ср. нем. reiten)

(sa) šikinet impf. (cp. нем. sich schicken)

šinfinat impf. (cp. нем. schimpfen

špacirinat impf. (ср. нем. spazieren)

(sa) štrajtinat (cp. нем. streiten)

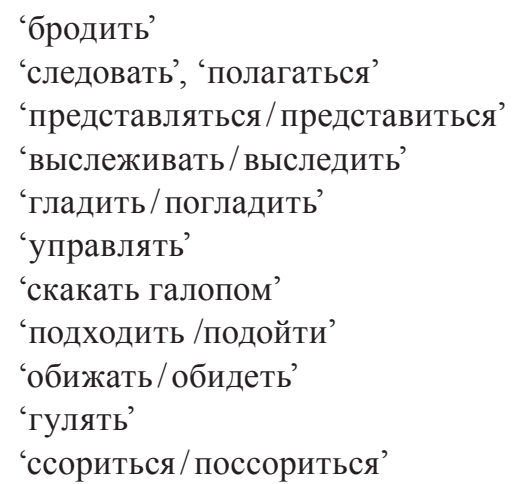

Глагол bondrinat появляется в формах vandrati и bandrati в StriedterTemps (1963: 245). По мнению автора, глагол восходит к свн. или нвн. формам wandern. Безлай тоже приводит форму vandrati с той же периодизацией (Bezlaj 1976-2007: 280). См. также Snoj 2003: 806.

5 Следует упомянуть, что, как было сказано с самого начала, резьянские глагольные формы с суффиксом -inat стоят особняком в словенском языковом диалектологическом ареале. Следовательно, они не появляются в этимологических словарях словенского языка. Вместо них появляются «соответствующие» формы, образованные чаще всего с помощью обыкновенного суффикса -at/-ati. 
Глагол (sa) kertinat не появляется ни в одном из используемых нами историко-этимологических исследований.

Глагол (sa) meltinat засвидетельствован в форме mẹldat в работе Striedter-Temps 1963: 178. Глагол восходит к свн. или нвн. melden.

Глагол pahtinat (точнее, аналогичная форма без суффикса -inat, типа pahtati) не засвидетельствован в используемых нами историко-этимологических исследованиях.

Глагол peglinat появляется в форме peglati в Striedter-Temps (1963: 191). По мнению автора, глагол отражает баварскую диалектную форму pögeln. См. также Bezlaj (1976-2007: 20).

Глагол ragirinat, в форме regirati, приводит Bezlaj (1976-2007: 167). Согласно его свидетельству, глагол восходит к свн. глаголу regieren. См. также Snoj 2003: 612.

Глагол rajtinat, точнее, форма rajtati в значении, указанном Матичетовым ${ }^{6}$, не засвидетельствован ни в одном из используемых историко-этимологических исследований. Однако Bezlaj (1976-2007: 146) приводит существительное rajtar 'всадник', связанное с свн. rîten 'ехать верхом', являющимся, по всей вероятности, немецким глаголом, который был заимствован в резьянском диалекте.

Глагол (sa) šikinet, точнеe, šikati se, приводят Bezlaj (1976-2007: 43) и Snoj (2003: 726), который считает, что глагол был заимствован в словенский язык в XVIII веке.

Глагол šinfinat, точнее, šimfat, засвидетельствован М. Сноем, который связывает его с двн. skimphen (Snoj 2003: 725).

Что касается глагола špacirinat, Striedter-Temps (1963: 222) приводит špancirati, часто появляющийся в народных словенских песнях, также в форме špacirat (без вторичной “ $n$ ”). По мнению автора, заимствование глагола, возможно, произошло в свн. (или в нвн.). Ср. также Snoj 2003: 735.

Последний глагол (sa) štrajtinat, в форме типа (sa) štrajtati, не засвидетельствован ни в одном из используемых историко-этимологических исследований.

Большинство рассмотренных глаголов, если исключить ragirinat и (sa) šikinet, которые уже вышли из употребления, все еще используется в резьянском диалекте, если не во всех его говорах, то во многих из них.

С хронологической точки зрения, этимологические исследования, на которые мы опирались, чаще всего указывают на средне-высоконемецкий (а также на ново-высоконемецкий) период употребления рассмотренных глагольных форм. Один раз (см. глагол šinfinat) указывается на более ранний период, т. е. на древне-высоконемецкий. Бывают и случаи, когда резьянские глаголы не зарегистрированы лексикографами, так как они не имеют соответствующих форм ни в других словенских диалектах,

6 См. омонимичный глагол, также распространенный в словенском языковом ареале и также заимствованный из немецкого (точнее, из свн. глагола reiten), однако имеющий совершенно другое значение, т. е. 'rechnen' (Striedter-Temps 1963: 207). 
ни в словенском литературном языке7. В данных случаях труднее выдвинуть какую-либо гипотезу о периоде их заимствования, хотя некоторые из них, судя по всему, были заимствованы относительно недавно, в течение XIX века.

Следует также заметить, что иногда, в резьянском диалекте, наряду с формой с суффиксом -inat появляются (иногда даже предпочитаются) варианты без суффикса. См., напр., sa štraitat наряду с (sa) štrajtinat, peglat наряду с peglinat и т. д. Такие случаи вариативности не встречаются в случаях с глаголами романского происхождения, описанными выше.

Если сравнить глаголы на -inat германского происхождения, проанализированные в этом разделе, с романскими заимствованиями, рассмотренными выше (\$1.1), отмечается одно важное сходство просодического характера: в обоих случаях ударение в языке-доноре падает на основу, т. е. на слог, предшествующий окончанию. В обоих случаях такая позиция сохраняется, и ударение заимствованного глагола также падает на основу. Возможно, именно это и было точкой соприкосновения, которая вела к «расширению» первичной морфологической модели от глаголов германского к более поздним глаголам романского происхождения, о котором будет сказано ниже.

Однако отмечаются и некоторые различия. Во-первых, глаголы на -inat германского происхождения не принадлежат к международной книжной лексике. Другая особенность этих глаголов, отличающая их от романских заимствований, состоит в том, что они не являются двувидовыми. Например, глаголы pücinat и trücinat могут образовывать приставочные формы $\mathrm{CB}$ посредством очень употребительной в резьянском диалекте приставки s- (spücinat и strücinat), в то время как глагол namulinat приводится непосредственно в приставочной производной форме (см. выше). Подобным образом, среди глаголов, приведенных Матичетовым, от šinfinat образуется форма СВ посредством приставки (zašinfinat). С другой стороны, глагол meltinat, видимо, из-за своей явно терминативной семантики, определяется автором как глагол СB, а все другие - как глаголы НCB, т. е., в конечном счете, как глаголы imperfectiva tantum, что в принципе и соответствует их длительной семантике.

На основе всего сказанного нами выдвигается гипотеза о том, что обсуждаемый здесь суффикс имеет германское происхождение. Точнее, он мог появиться сначала в результате интеграции глаголов, заимствованных из баварско-каринтийских говоров, начиная с средне-высоконемецкого периода8: окончание инфинитива -en, претерпевшее редукцию гласного, стало инфиксом, к которому прибавлялось «типичное» резьянское окончание инфинитива -at. Это новое двуслоговое окончание -inat, которое выделя-

\footnotetext{
7 Это само по себе интересное явление, причины которого заслуживают углубленного изучения. См. об этом Matičetov 1975: 118.

8 Следов более ранних заимствований, восходящих к древне-высоконемецкому (если исключить случай глагола šinfinat), найти не удалось.
} 
лось среди других окончаний инфинитива резьянского диалекта, после того, как влияние немецкого языка сильно уменьшилось и роль языкадонора начал играть фриульский (вместе с венецианским и затем с итальянским), стало удобным маркером, обозначающим заимствованные глаголы вообще, т. е., в основном глаголы романского происхождения. Наконец оно «специализировалось» как формант для образования иностранной, международной глагольной лексики латинского происхождения, принадлежащей

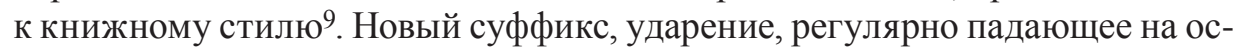
нову, и биаспективность стали как бы отличительными признаками для этих особых, не исконных глаголов, способствуя их узнаваемости.

Гипотеза становится более понятной и приобретает больший вес, если принимать во внимание происхождение и судьбу суффикса -isati а также, в какой-то мере, -irati в сербском и хорватском языках.

\section{2. Глаголы на -isati в сербском и хорватском языках}

Известно, что в современном сербском и, хотя и в меньшей мере, хорватском языках имеется очень продуктивный, открытый класс глагольных заимствований, характеризующихся окончанием -isati ${ }^{10}$. Проблема происхождения этого окончания была впервые детально изучена П. Скоком в двух работах (Skok 1955/56 и 1957). Он считает, что морфема -isati имеет иностранное происхождение и восходит к греческому сигматическому аористу, точнее, к аористическому форманту -is-. Греческие аористические формы, которые повлияли на образование данного суффикса, были не столько формами прошедшего времени изъявительного наклонения (выражающими временные отношения), сколько формами, лишенными настоящей временной семантики, как императив, футурум и сослагательное наклонение ${ }^{11}$. Суффикс -is- как формант греческих глагольных заимствований ${ }^{12}$ распространился по всему балканскому ареалу, т. е. не только на восточной тер-

9 Бывают и случаи (правда, редкие), когда функцией суффикса является просто создавать глаголы посредством «внутреннего» образования от таких заимствованных слов, как существительные (см. kuntinat <kont) или наречия (см. forinat $<$ fora) (устное сообщение $\mathrm{X}$. Стэнвейка). Как мы увидим дальше, аналогичные явления встречаются также в сербском и в хорватском языках в связи с суффиксами -isati и -irati (см. сноску 12).

10 Как отмечают разные ученые, территориальная дистрибуция этого суффикса (как и суффикса -irati, о котором будет сказано ниже) колеблется (Skok 1955/56, Јоџић 1969).

11 Следует упомянуть, что, начиная примерно с ХІ века (хотя свидетельства употребления конструкций с ívo в функции инфинитива появлялись еще раньше), именно сослагательное наклонение постепенно заменило инфинитив в греческом языке. Такая черта (отсутствие инфинитива и замена его сослагательными формами), как известно, вообще является одной из главных характеристик языков балканского ареала.

12 Суффикс мог играть глаголообразующую функцию также в применении к существительным (или другим неглагольным формам) иностранного происхождения и к «автохтонным» глагольным и именным основам (Skok 1957: 139). Эта тенденция, которая отмечалась также в резьянском диалекте (см. выше сноску 9), характеризует и современные сербский и хорватский языки, по отношению как к суффиксу -isati, так и к-irati (cм. Ć́rić 2016 и Grčević 2016). 
ритории сербохорватского континуума, но и в болгарском, румынском и албанском языках (Skok 1955/56: 37-38 и 1957: 139). Везде он стал затем применяться к глаголам, заимствованным из турецкого языка, прибавляясь к основе либо инфинитива, либо претерита, образованного посредством форманта -d- (см. eglenisati / eglendisati, kulanisati / kulandisati) (Skok 1955/56: 37-38). Наконец, в сербском языке суффикс стал применяться к иностранным глаголам вообще, особенно латинского происхождения ${ }^{13}$.

В. Брой тоже пишет об исконно греческой (точнее, новогреческой) морфеме -s-, которая во всем балканском ареале постепенно стала морфологическим признаком глагольных заимствований вообще. Он говорит по этому поводу о «морфологической внутренней динамике» (morphologische Eigendynamik), характеризующей те ситуации, когда определенная морфема, вычлененная из более древних заимствований, становится продуктивным, динамическим элементом для процесса заимствования как такового, независимо от конкретной структуры глагола, являющегося объектом заимствования (Breu 1991: 44).

Подтверждает эту гипотезу Ф. Гардани, который, однако, предпочитает говорить о перфективной (а не об аористической) форме, имея в виду главную, именно перфективирующую функцию темы греческого аориста. Подчеркивая «иностранное» начало такого способа интеграции заимствований, автор определяет его как явление «аллогенной экзаптации» (allogenous exaptation), т. е. как диахроническое явление, появляющееся в ситуации языкового контакта, предусматривающее изменение исконной грамматической функции морфемы при переходе из одного языка в другой. По мнению автора, в случае сербского языка греческий формант -s- (точнее, -(i)s-) в процессе вычленения из языка-донора и адаптации к языкуреципиенту потерял исконную функцию маркера СВ и стал словообразующим элементом, притом очень продуктивным, для интеграции иностранных глаголов: сначала греческих, затем турецких, а еще позже, глаголов иностранного происхождения вообще, особенно французского (Gardani 2016: 243).

Среди работ, которые рассматривали глагольный суффикс -isati следует еще назвать работу Јоцић 1969 , где точно определяется хронология явления. По мнению автора, суффикс -isati появляется впервые в сербском языке в XII веке, т. е. начиная с первых сербских документов, в применении к глаголам, заимствованным из греческого (точнее, из византийско-греческого) языка ${ }^{14}$. Затем, начиная с XVII века, он стал появляться с турецкими

13 Интересно отметить, что этот последний этап не имел места в болгарском языке, где данный суффикс, как правило, употребляется только для заимствований турецкого происхождения. Для образования глагольных заимствований международного, «книжного» характера используется -ирам (а также -изирам), т. е. суффикс немецкого происхождения, о котором будет сказано ниже (§3).

14 Такое уточнение, отодвигающее назад, по сравнению с предыдущими исследованиями, период распространения анализируемого типа морфологического заимствования, 
глагольными заимствованиями, и такая тенденция продолжалась (и укреплялась) в XVIII и XIX веках.

Следует также упомянуть фундаментальную работу И. Клайна о словообразовании, где автор детально анализирует глаголы на -isati в современном сербском языке, специально различая случаи, когда глаголы производятся от заимствованных глаголов и от именных основ, при этом не только иностранного, но и «внутреннего» происхождения (Клајн 2003: 339-341). Автор подчеркивает также, что в современном сербском языке глаголы на -isati чаще всего являются биаспективами. См. также по этому поводу Спасоевић 2015: 249.

Вот некоторые глаголы на -исаӣu, взятые из Клајн 2003 (340): афир-

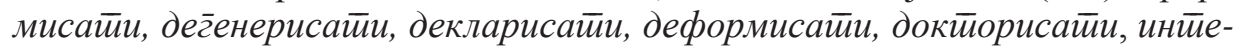

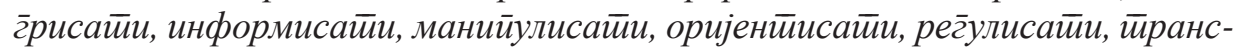
формисайи, и т. д.

\section{3. Глаголы на -irati в сербском и хорватском языках}

Подобное развитие характеризует суффикс -irati (см. также вариант -izirati), распространенный скорее в хорватском варианте сербохорватского континуума 15 . По свидетельству М. Јоцић, суффикс был заимствован в XVII веке из немецкого языка (Јоцић 1969: 122; см. также по этому поводу Клајн 2003: 352-353, Спасојевић 2015: 229), где формант -ier имел функцию маркирования заимствованных глаголов, а также образования глагольных форм от номинальных (чаще иностранного, но также и внутреннего происхождения). В немецкий (средне-высоконемецкий) язык, однако, окончание вошло гораздо раньше: оно было заимствовано из французского языка (см. -er/-ir) 16 $^{16}$ XI-XII веках, когда французская куртуазная культура распространялась по всей Европе, существенным образом влияя на развитие средненемецкого языка, особенно на его лексику (Gardani 2016: 238. См. также Skok 1956/57: 39, Јоџић 1969). При этом к окончанию исконного французского глагола (развившемуся как -ir) прибавлялось типичное немецкое окончание инфинитива -еn (см. -ieren).

кажется нам вполне удовлетворительным. На самом деле нельзя исключить, что -isati начало распространяться среди славянского населения еще раньше, сразу после переселения на Балканы, т. е. начиная с VII века, особенно на болгарских и македонских территориях, находившихся в более тесном контакте с греческим ареалом. В сербском языке употребление данного окончания могло бы начаться чуть позже, во время христианизации и вхождения сербских жуп в болгарское культурное пространство. Нужно также иметь в виду, что, когда речь идет о таких явлениях конвергентного развития, характеризующих Балканский союз, как интересующий нас суффикс, почти невозможно установить хронологию, точнее, временную последовательность, с которой имели место явления (например, в каком из соседних языков впервые произошел тот или иной процесс аллогенной экзаптации). См. по этому поводу Gardani 2016: 242, сноску 24.

15 См. сноску 10. См. также Спасоевич 2015: 230-231, где подчеркивается высокая частотность данного суффикса на всей бывшей сербохорватской территории.

16 Суффиксы являются рефлексом латинского глагольного суффикса -āre/-īre. 
Новый суффикс был долго продуктивным в немецком языке ${ }^{17}$. Отсюда он перешел, с той же функцией маркера заимствованных глаголов, в разные славянские языки: в русский, болгарский и, что для нас важнее, в сербский и, в еще большей мере, в хорватский, находившийся веками в тесном контакте с немецким ареалом.

В современных сербском и хорватском языках глаголы, образованные посредством суффикса -irati, обладают теми же особенностями, которые характеризуют глаголы, образованные посредством суффикса -isati: они образуют продуктивный класс двувидовых глаголов, связанных с иностранной, международной лексикой латинского происхождения.

Ср., например, следующие глаголы, взятые из Клајн 2015 (354): анке-

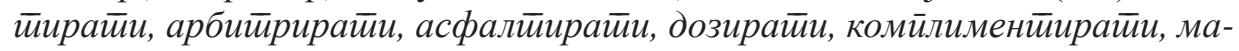

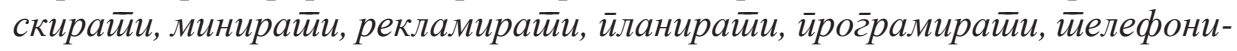
райи, и т. д.

Однако глаголы на -irati не являются результатом исторического процесса «морфологической внутренней динамики», по определению Броя (или «аллогенной экзаптации», по определению Гардани). Такой процесс осуществился раньше, внутри германского языкового ареала, а в сербский и хорватский языки он перешел потом, уже «в готовом виде», с теми же грамматическими функциями, которые суффикс постепенно приобрел во время своего пребывания внутри немецкого ареала. Иными словами, перед нами просто случай ординарного заимствования.

\section{Заключение}

Проведенный сравнительный анализ глагольного суффикса -inat в резьянском диалекте, с одной стороны, и -isati в сербском и хорватском языках, с другой, позволил найти существенные сходства в их поведении. В обеих ситуациях речь идет о форманте, заимствованном в более древний период под влиянием иностранного языка, имевшего в то время «престижную» роль. Это случай немецкого языка для резьянского диалекта и греческого языка для сербского (и хорватского).

Что касается первого случая, известно, что перед вселением в долину Резии (которое имело место не позднее, чем в X-XI веках) ${ }^{18}$ предки резьянцев жили в Каринтии, в контакте с баварским населением. После вселения и до начала XV века немецкий язык, будучи языком, на котором говорили представители административной и религиозной властей (имеется в виду Аквилейский патриархат, а также Аббатство Моджо), продолжал играть

17 В современном немецком литературном языке суффикс больше не является продуктивным.

$18 \mathrm{O}$ том, когда именно предки резьянцев вселились в долину Резии, надежного свидетельства нет. Возможно, это случилось уже в VII веке (см. Grafenauer 1970/71: 27) но, возможно, и позже, примерно в X-XI веках, во время колонизации (и восстановления) Фриули под управлением франко-баварских феодалов после нашествия нашествия венгров (см. Kos 1955: 63). 
важную роль в развитии этого словенского идиома. К этому времени относится большинство именных и глагольных заимствований, присутствующих в резьянском диалекте, включая многие из проанализированных глаголов на -inat. Когда Фриульская область отошла к Венецианской Республике и контакт с немецким языком сильно ослабился ${ }^{19}$, суффикс стал применяться в основном к новым глагольным заимствованиям, принадлежащим уже к романскому языковому ареалу. Наконец, суффикс стал отличительным маркером иностранных глаголов вообще, особенно тех, которые принадлежат к международной лексике книжного типа.

Подобную роль играл греческий язык (византийский и затем новогреческий) для сербского и хорватского языков: суффикс -isati стал употребляться при заимствовании греческих глаголов, а когда (начиная с XV века) роль греческого языка как «престижного» стала убывать за счет турецкого языка, суффикс постепенно стал употребляться для интеграции турецких глагольных заимствований и наконец стал универсальным маркером иностранных глаголов вообще, не принадлежащих, собственно говоря, к определенным языкам, а ощущаемых как интернационализмы.

Резьянские глаголы на -inat и сербские (и хорватские) глаголы на -isati разделяют и другую важную особенность: они не интегрируются в видовую систему славянского языка-реципиента и в основном остаются двувидовыми. Таким образом, «новые» глаголы выделяются среди всех остальных, и их иностранное происхождение становится прозрачным. И действительно, как отмечает Гардани (Gardani 2016: 247, 254), одной из главных характеристик «аллогенной экзаптации» является именно ее «систематизирующая функция» т. е. функция, обеспечивающая на синхронном уровне узнаваемость заимствованной лексики.

Все сказанное касается только отчасти суффикса -irati, так как в данном случае процесс «аллогенной экзаптации» произошел не внутри славянского языка-реципиента, а вне его, осуществившись лишь впоследствии как простой случай морфологического заимствования.

Итак, проведенный сравнительный анализ, как нам кажется, с одной стороны предлагает объяснение происхождения в резьянском диалекте суффикса -inat, считающегося до сих пор загадочным, а с другой вносит вклад в изучение теории языкового контакта и, в частности, процессов интеграции заимствований, приводя новый, пока неизученный пример явления «аллогенной экзаптации».

Остается еще ответить на два вопроса, о которых мы упомянули только мимоходом. Первый касается того факта, что глаголы на -inat германского происхождения могут допускать вариацию с формами, образованными с суффиксом -at (см. peglinat/peglat), в то время как романские глаголы

19 Правда, как мы увидели, немецкие заимствования продолжали появляться и в последующие века, особенно в связи с явлением рабочей сезонной эмиграции в австрийские города, долго характеризовавшим резьянскую экономику. Однако эти случаи были уже редки. 
такой вариации не допускают. Такую безусловно любопытную особенность можно, вероятно, объяснить тем, что германские заимствования представляют собой просто начальную фазу описанного диахронического процесса «аллогенной экзаптации», который только со временем превратился в регулярную, «структурированную» модель.

Второй вопрос касается того факта, что в других словенских диалектах, бытующих во Фриули (т. е. в терском и надижском), и вообще в словенском литературном ареале такой суффикс не встречается. Наверное, причина такого различия в поведении кроется в особенно значимом контакте с германским населением в той географической зоне, где жили предки резьян до их вселения во Фриули или в ранние этапы после вселения. Об этом, однако, нет никаких конкретных языковых или исторических данных, на которые можно было бы опираться, и вопрос остается открытым.

\section{СОКРАЩЕНИЯ}
двн. древне-высоконемецкий
свн. средне-высоконемецкий
нвн. ново-высоконемецкий
нем. немецкий
фp. фриульский
ит. итальянский
вен. венецианский

\section{ЛИТЕРАТУРА}

Бенаккьо Розанна. «Славянороманские контакты во словенских говорах Фриули». Татьяна Николаева (отв. ред.). Славянская языковая и этноязыковая системы в контакте с неславянским окружением. РАН. Институт славяноведения РАН. Москва: Языки славянской культуры, 2002: 263-300.

Бенаккьо Розанна. «Интеграция заимствованных глаголов в славянскую видовую систему». Славистика XXII/1 (2018): 9-20.

Бенаккьо Розанна. «Суффиксация как средство образования видовых пар в резьянском диалекте: славянская и иноязычная лексика». Maria Chiara Ferro et al. (red.). Contributi italiani al XVI Congresso internazionale degli Slavisti (Belgrado 20-27.VIII.2018). Firenze: Firenze University Press, 2018: 153-162.

Бенаккьо Розанна, Стэнвейк Хан. «Префиксация и суффиксация как способы грамматикализации глагольного вида в резьянском диалекте: исконно-славянская и романская лексика. Benacchio Rosanna et al. (ed.). The role of prefixes in the formation of aspectuality. Firenze: Firenze University Press, 2017.

Јоцић Мирјана. „Глаголи са суфиксима -иса -ира, -ова у савременом српскохрватском књижевном језику“. Прилози йроучавању језика 5 (1969): 121-175.

Клајн Иван. Творба речи у савременом срйском језику. II: Суфиксаиија и конверзија. Београд: Завод за уџбенике и наставна средства, 2003.

Спасојевић Марина. Двовидски гллаголи у савременом срйском језику. Докторска дисертација. Београд: Филолошки факултет Универзитета у Београду, 2015.

Benacchio Rosanna. I dialetti sloveni del Friuli tra periferia e contatto. Udine: Società Filologica Friulana, 2002.

Benacchio Rosanna. "Sulle orme di M. Matičetov: i prestiti verbali dal tedesco". Marija Stanonik, Han Steenwijk (eds). Tra ricerca sul campo e studio a tavolino: contributi per i cento anni dalla nascita dell'accademico Milko Matičetov/Med terenom in kabinetom: ob 100. obletnici rojstva akademika Milka Matičetovega, Padova: Cleup, in c. di stampa. 
Bezlaj France. Etimološki slovar slovenskega jezika. I-V. Ljubljana: Slovenska Akademija znanosti in umetnosti. Inštitut za slovenski jezik. Založila Mladinska knjiga, 1976-2007.

Breu Walter. „Abweichungen vom phonethischen Prinzip bei der Integration von Lehnwōrtern“" Klaus Hartenstein, Helmut Jachnow (hrsg.). Slavistische Linguistik 1990. München: Otto Sagner, 1991: 36-59.

Breu Walter. „System und Analogie bei der Integration von Lehnwōrtern: Versuch einer Klassifikation". Incontri linguistici 14 (1991a): 13-28.

Ćorić Božo. „Serbian“. Peter O. Müller et al. (ed.). Word-formation. An international handbook of the languages of Europe. Berlin-Boston: De Gruyter Mouton, 2016: 3017-3037.

Gardani Francesco. „Allogenous exaptation“. Muriel Norde, Freek Van de Velde (ed.), Exaptation and Language Change, John Benjamins Publishing Company, 2016: 227-260.

Grčević Mario. „Croatian“. Peter O. Müller et al. (ed.). Word-formation. An international handbook of the languages of Europe. Berlin-Boston: De Gruyter Mouton, 2016: 2998-3016.

Matičetov Milko. "Per la conoscenza degli elementi tedeschi nel dialetto sloveno di Resia". Grazer lingvistische Studien 2. Graz, 1975: 116-137.

Skok Petar. "O sufiksima -isati, -irati i -ovati”. Jezik IV/2, 1955-56: 36-43.

Skok Petar. „Die neugrichiescen Verbalsuffixe -izō, -euō und -onō in den Balkansprachen“. Mnēmēs Hari. Gedenkschrift Paul Kretschmer. II. Wien: Otto Harrassowitz - Brüder Hollinek, 1957: 138-141.

Snoj Marko. Slovenski etimološki slovar. Ljubljana: Modrijan, 2003.

Steenwijk Han. The Slovene dialect of Resia. San Giorgio [Studies in Slavic and General Linguistics 18], Amsterdam-Atlanta, GA: Rodopi, 1992.

Steenwijk Han. Piccolo dizionario ortografico resiano/Mali bisidnik za tö jošt rozajanskë pïsanjë. Padova: CLEUP, 2005.

Steenwijk Han. "La fonologia storica del resiano alla luce dei prestiti tedeschi". Marija Stanonik, Han Steenwijk (eds). Tra ricerca sul campo e studio a tavolino: contributi per i cento anni dalla nascita dell'accademico Milko Matičetov/Med terenom in kabinetom: ob 100. obletnici rojstva akademika Milka Matičetovega, Padova: Cleup, in c. di stampa.

Striedter-Temps Hildegard. Deutsche Lehnwörter im Slovenischen. Berlin: Otto Harrassowitz, 1963.

\section{LITERATURE}

Benacchio Rosanna. I dialetti sloveni del Friuli tra periferia e contatto. Udine: Società Filologica Friulana, 2002.

Benacchio Rosanna. «Slavyanoromanskie kontakty vo slovenskih govorah Friuli». Tatyana Nikolaeva (otv. red.). Slavyanskaya yazykovaya i etnoyazykovaya sistemy v kontakte s neslavyanskim okruzheniem. Institut Slavjanovedenija RAN. Moskva: YAzyki slavyanskoj kul'tury, 2002: 263-300.

Benacchio Rosanna. «Integraciya zaimstvovannyh glagolov v slavyanskuyu vidovuyu sistemu». Slavistika XXII/1 (2018): 9-20.

Benacchio Rosanna. «Suffiksaciya kak sredstvo obrazovaniya vidovyh par v rez'yanskom dialekte: slavyanskaya i inoyazychnaya leksika». Maria Chiara Ferro et al. (red.). Contributi italiani al XVI Congresso internazionale degli Slavisti (Belgrado 20-27.VIII.2018). Firenze: Firenze University Press, 2018: 153-162.

Benacchio Rosanna. "Sulle orme di M. Matičetov: i prestiti verbali dal tedesco". Marija Stanonik, Han Steenwijk (eds). Tra ricerca sul campo e studio a tavolino: contributi per i cento anni dalla nascita dell'accademico Milko Matičetov/Med terenom in kabinetom: ob 100. obletnici rojstva akademika Milka Matičetovega, Padova: Cleup, in c. di stampa.

Benacchio Rosanna, Steenwijk Han. «Prefiksaciya i suffiksaciya kak sposoby grammatikalizacii glagol'nogo vida v rez'yanskom dialekte: iskonno-slavyanskaya i romanskaya leksika. Benacchio Rosanna et al. (ed.). The role of prefixes in the formation of aspectuality. Firenze: Firenze University Press, 2017.

Bezlaj France. Etimološki slovar slovenskega jezika. I-V. Ljubljana: Slovenska Akademija znanosti in umetnosti. Inštitut za slovenski jezik. Založila Mladinska knjiga, 1976-2007. 
Breu Walter. „Abweichungen vom phonethischen Prinzip bei der Integration von Lehnwōrtern“. Klaus Hartenstein, Helmut Jachnow (hrsg.). Slavistische Linguistik 1990, München: Otto Sagner, 1991: 36-59.

Breu Walter. „System und Analogie bei der Integration von Lehnwōrtern: Versuch einer Klassifikation". Incontri linguistici 14 (1991a): 13-28.

Ćorić Božo. „Serbian“. Peter O. Müller et al. (ed.). Word-formation. An international handbook of the languages of Europe. Berlin-Boston: De Gruyter Mouton, 2016: 3017-3037.

Gardani Francesco. „Allogenous exaptation“. Muriel Norde, Freek Van de Velde (ed.), Exaptation and Language Change, John Benjamins Publishing Company, 2016: 227-260.

Grčević Mario. „Croatian“. Peter O. Müller et al. (ed.). Word-formation. An international handbook of the languages of Europe. Berlin-Boston: De Gruyter Mouton, 2016: 2998-3016.

Jocić Mirjana. „Glagoli sa sufiksima -isa -ira, -ova u savremenom srpskohrvatskom književnom jeziku“. Prilozi proučavanju jezika 5 (1969): 121-175.

Klajn Ivan. Tvorba reči u savremenom srpskom jeziku. II: Sufiksacija i konverzija. Beograd: Zavod za udžbenike i nastavna sredstva, 2003.

Matičetov Milko. "Per la conoscenza degli elementi tedeschi nel dialetto sloveno di Resia". Grazer lingvistische Studien 2. Graz, 1975: 116-137.

Skok Petar. "O sufiksima -isati, -irati i -ovati". Jezik IV/2, 1955-56: 36-43.

Skok Petar. „Die neugrichiescen Verbalsuffixe -izō, -euō und -onō in den Balkansprachen“. Mnēmēs Hari. Gedenkschrift Paul Kretschmer. II. Wien: Otto Harrassowitz — Brüder Hollinek, 1957: 138-141.

Snoj Marko. Slovenski etimološki slovar. Ljubljana: Modrijan, 2003.

Spasojević Marina. Dvovidski glagoli u savremenom srpskom jeziku. Doktorska disertacija. Beograd: Filološki fakultet Univerziteta u Beogradu, 2015.

Steenwijk Han. The Slovene dialect of Resia. San Giorgio [Studies in Slavic and General Linguistics 18], Amsterdam-Atlanta, GA: Rodopi, 1992.

Steenwijk Han. Piccolo dizionario ortografico resiano/Mali bisidnik za tö jošt rozajanskë pïsanjë. Padova: CLEUP, 2005.

Steenwijk Han. "La fonologia storica del resiano alla luce dei prestiti tedeschi". Marija Stanonik, Han Steenwijk (eds). Tra ricerca sul campo e studio a tavolino: contributi per i cento anni dalla nascita dell'accademico Milko Matičetov/Med terenom in kabinetom: ob 100. obletnici rojstva akademika Milka Matičetovega, Padova: Cleup, in c. di stampa.

Striedter-Temps Hildegard. Deutsche Lehnwörter im Slovenischen. Berlin: Otto Harrassowitz, 1963.

Розана Бенакио

\author{
СУФИКС -INАТ У РЕЗЈАНСКОМ ДИЈАЛЕКТУ \\ И ЮЕГОВЕ ПАРАЛЕЛЕ У СРПСКОМ И ХРВАТСКОМ ЈЕЗИКУ
}

\title{
Резиме
}

Чланак је посвећен суфиксу -inat који се користи у резјанском дијалекту (у источном делу провинције Фријули, на граници Италије и Словеније) за означавање глаголских позајмљеница романског (углавном фријуланског) порекла. То су биаспективни глаголи који најчешће припадају међународној књижевној лексици. Износи се хипотеза да се овај суфикс појавио под утицајем немачког језика (тачније, инфинитивног наставка -en), који је играо значајну улогу у развоју резјанског дијалекта барем до XV века, тј. до пада Аквилејске патријаршије и уласка Фријула у састав Венецијанске Републике. Сличан процес може се испратити и у српском и, премда у мањој мери, у хрватском језику у погледу суфикса -isati, који такође означава биаспективне глаголске позајмљенице међународне лексике, и за који се сматра да је настао као резултат интеграције суфикса -s- грчког аориста.

Кључне речи: глаголске позајмљенице, резјански дијалекат, суфикс -inat, српски и хрватски језик, суфикс-isati. 